Paweł Miśkowiec

Uniwersytet Jagielloński,

Wydział Chemii, Zakład Chemii Środowiska

Kraków

\title{
200 LAT WYKORZYSTANIA KADMU W NAUCE, TECHNICE I SZTUCE
}

\section{Wstęp}

W 1817 r. został odkryty kadm - metal, dzięki któremu rozwinęło się i nadal rozwija szereg gałęzi przemysłu, w tym kluczowy dla gospodarki przemysł energetyczny. Odkrycie tego pierwiastka oraz jego barwnych soli przyczyniło się również do powstania nowych kierunków w światowym malarstwie, takich jak impresjonizm czy fowizm. Zapotrzebowanie na ten i jemu pokrewne metale (cynk i ołów) spowodowało jednak uwolnienie do obiegu biogeochemicznego znacznych ilości tego pierwiastka, przez co ujawniła się również jego „druga twarz”, czyli wysoka toksyczność dla organizmów żywych, w tym dla człowieka ${ }^{1}$.

\section{Odkrycie kadmu}

Historia odkrycia kadmu rozpoczyna się na początku XIX wieku i jak wiele odkryć tego okresu ma w sobie nutkę sensacji. Głównymi postaciami na scenie są: Friedrich Stromeyer - profesor chemii i farmacji na uniwersytecie w Getyndze, Johann Christoph Heinrich Roloff - lekarz i jednocześnie inspektor farmaceutyczny z Magdeburga oraz Karl Samuel Leberecht Hermann - farmaceuta, założyciel i właściciel fabryki chemicznej w Schönebeck pod Magdeburgiem.

W roku 1817 Friedrich Stromeyer objął funkcję Generalnego Inspektora Aptek królestwa Hanoweru. Jednym z jego zadań była między innymi kontrola czystości

\footnotetext{
${ }^{1}$ M. Jakubowski: Kadm i jego zwiqzki nieorganiczne - w przeliczeniu na Cd, „Podstawy i Metody Oceny Środowiska Pracy" 2012 vol. 2 (72), s. 111-146.
}

Kwartalnik Historii Nauki i Techniki R. 63: 2018 nr 2 s. 131-141 
chemicznej farmaceutyków². W owym czasie jedną z popularniejszych substancji chemicznych, dodawaną do wielu lekarstw był tlenek cynku ZnO, który w czystej postaci ma barwę białą. Podawano go doustnie przy nieżytach przewodu pokarmowego, owrzodzeniach jelit, a nawet padaczce i nerwicach objawiających się drgawkami. Stosowany też był (i jest do dzisiaj) zewnętrznie jako antyseptyk ${ }^{3}$. Nie dziwi więc, przy takiej popularności leków na bazie tlenku cynku, jednoczesne zainteresowanie wizytatorów ich jakością. Jesienią 1817 Stromeyer wizytował apteki w okolicach miejscowości Hildesheim pod Hanowerem. Znany z pracowitości i skrupulatności inspektor kontrolował apteki według ustalonego, lecz niejawnego planu, na skutek czego aptekarze nie wiedzieli, kiedy spodziewać się kontroli ${ }^{4}$. Przeglądając podczas wizytacji stany magazynowe aptek Stromayer odkrył, iż w całym regionie przy preparowaniu odpowiednich leków aptekarze wykorzystywali węglan cynku $\mathrm{ZnCO}_{3}$ (również naturalnie biały) zamiast przepisowego tlenku cynku ZnO. Wszystkie badane apteki zaopatrywały się w węglan cynku w manufakturze z miejscowości Saltzgitter położonej ok. $30 \mathrm{~km}$ od Hildesheim. Dochodzenie Stromeyera wykazało, że zamiana podyktowana była faktem, iż po wyprażeniu węglanu cynku w manufakturze w Saltzgitter otrzymywano tlenek cynku, który zamiast przewidywanej śnieżno białej barwy miał kolor lekko żółtawy. Dyrektor manufaktury zapewniał Stromeyera, że to przebarwienie pojawia się za każdym razem, pomimo stosowania najwyższych, znanych w owym czasie, standardów oczyszczania substratów. Tlenek cynku o takiej barwie okazał się być jednak praktycznie niesprzedawalny. Właściciel manufaktury zdecydował się zatem obejść problem i dostarczać do aptek biały węglan cynku zamiast żółtawego tlenku cynku . Źródła nie podają, czy aptekarze byli świadomi tego procederu, można jednak domniemywać, że czynnik ekonomiczny powodował, że dopuszczali zamianę, która według nich nie wpływała na jakość produkowanych leków. Niewytłumaczalne zachowanie węglanu cynku podczas prażenia spowodowało iż Stromeyer przeprowadził jego wstępne analizy. Po doświadczalnym wykluczeniu zanieczyszczenia arsenem i ołowiem, wysnuł hipotezę, że żółtawa barwa musi pochodzić od domieszki tlenku innego metalu.

Aby potwierdzić swoje przypuszczenia profesor z Getyngi rozpuścił zanieczyszczony tlenek cynku w kwasie siarkowym(VI), a następnie przepuścił przez roztwór siarkowodór. Warunki zostały tak dobrane, aby nie strącił się siarczek cynku. Uzyskany osad, już bez cynku, Stromeyer przefiltrował i przepłukał, po czym rozpuścił,

${ }^{2}$ A. Hirsch, A. Wernich, E.J. Gurlt: Biographisches Lexikon der hervorragenden Aerzte aller Zeiten und Völker, Wien 1886, vol. 5, s. 566.

${ }^{3}$ H. Róż a ńs ki : Tlenek cynku - Zincum oxydatum w medycynie XVIII i XIX wieku, [w:] Medycyna dawna i współczesna. Zasób internetowy: http://rozanski.li/1495/tlenek-cynku-zincum-oxydatum-w-medycynie-xviii-i-xix-wieku/ dostęp 22.09.2017.

${ }^{4}$ G. L o cke ma n n, R.E. O e s p e r: Friedrich Stromeyer and the history of chemical laboratory instruction, „Journal of Chemical Education” 30: 1953 nr 4 s. 202.

${ }^{5}$ Tamże, s. 203-204. 
tym razem w kwasie azotowym(V). Nadmiar kwasu został odparowany do sucha. Azotan(V) nieznanego pierwiastka został rozpuszczony w wodzie, po czym Stromeyer dodał do roztworu węglan amonu w znacznym nadmiarze. Uzyskany osad węglanu nowego pierwiastka został odfiltrowany, przepłukany i ogrzany, dzięki czemu Stromeyer otrzymał brązowawy tlenek. Po zmieszaniu z węglem drzewnym i redukcji w wysokiej temperaturze profesorowi w Getyndze po raz pierwszy udało się uzyskać niebiesko szary metal ${ }^{6}, 7$. Ilość nowego pierwiastka, który był w stanie wytworzyć powyższą techniką z zanieczyszczonego tlenku cynku, była jednak na tyle niewielka, że trudno mu było przeprowadzać dalsze badania właściwości fizykochemicznych odkrytego metalu. Profesorowi sprzyjało jednak szczęście. W tym samym bowiem czasie (jesień 1817) mniej więcej sto kilometrów na wschód, w Saksonii, podobne kontrole przeprowadzał Johann Christoph Heinrich Roloff. Zauważył on w kilku prowincjonalnych aptekach dziwnie wyglądający tlenek cynku o barwie odbiegającej od śnieżnobiałej - typowej dla ZnO. Jak się okazało, podejrzany związek chemiczny był każdorazowo kupowany w wyjątkowo niskiej cenie z fabryki chemicznej Carla Samuela Hermanna w Schönebeck. Fabrykant zaopatrywał się w ów nietypowy tlenek cynku na Śląsku, gdzie otrzymywano ten związek jako produkt uboczny przeróbki rudy cynku ${ }^{89}$. Testowa reakcja próbki tlenku z siarkowodorem dała żółtawy osad. Jako że siarczek cynku powinien mieć barwę białą, zaalarmowany Roloff skonfiskował cały zapas nietypowego tlenku, podejrzewając zanieczyszczenie związkami arsenu (arsen reagując z siarkowodorem daje żółty siarczek arsenu(III)). Próbki zostały wysłane do sprawdzenia do Berlina. Roloff jednak kontynuował pracę nad domniemanym zanieczyszczeniem na własną rękę i po serii eksperymentów doszedł do wniosku, że ma do czynienia najprawdopodobniej z nowym pierwiastkiem. Niezależnie od Roloffa, Carl Hermann - fabrykant i farmaceuta z Schönebeck, również samodzielnie wyekstrahował nowy metal z „trefnego” tlenku cynku, a próbkę wysłał do... Friedricha Stromeyera do Getyngi ${ }^{10}$. Profesor mając zatem próbki z Hildesheim oraz Saksonii ostatecznie upewnił się, że ma do czynienia z nowym metalem, któremu prawdopodobnie jeszcze w 1817 r. nadał nazwę kadmium. Swoje wyniki getyński uczony opublikował już w 1818 r. w czasopiśmie Journal für Chemie und Physik, które wydane zostało jednak z datą roczną 1817. To właśnie wtedy

\footnotetext{
${ }^{6}$ F. Stro m eye r: Ein neu entdecktes Metall und Analyse eines neuen Minerals, „Journal für Chemie und Physik" 21: 1817 s. 297-306.

${ }^{7}$ E. Turner: Elements of chemistry including the recent discoveries and doctrines of the science, Philadelphia 1832, s. 337.

${ }^{8}$ M. Fontani, M. Costa, M.V. Orna: The Lost Elements: The Periodic Table's Shadow Side, New York 2014, s. 59.

${ }^{9}$ J.C.H. Ro l off: Fortgesetzte Untersuchungen über die Reinheit der Zinkblumen, und wahrscheinliche Entdeckung eines neuen Metalls in denselben“, „Journal der Praktischen Heilkunde” 4: 1818 s.126-127.

${ }^{10}$ F. Stro m eyer: Ein neu entdecktes Metall und Analyse eines neuen Minerals, „Journal für Chemie und Physik" 21: 1817 s. 303.
} 
wspomniana nazwa kadmium pojawia się po raz pierwszy ${ }^{11}$. W lutym 1818 r. również Roloff wysłał wyniki swoich badań do czasopisma Journal fur die praktischen Heilkunde. Wydanie publikacji przeciągnęło się jednak aż do kwietnia ${ }^{12}$. Sytuacja zaczęła się komplikować, gdyż w międzyczasie o odkryciu nowego pierwiastka donieśli badacze z Berlina: D. Kluge i H. Staberoh, którzy analizowali próbki wysłane przez Roloffa. Zaproponowali oni nawet nazwę dla nowego metalu - klaprothium na cześć zmarłego rok wcześniej chemika Martina Klaprotha ${ }^{13}$. W kwietniu 1818 r. nieświadom niczego Roloff wysłał również próbkę metalu do Stomeyera z sugestią, iż odkrył najprawdopodobniej nowy pierwiastek i w przypadku potwierdzenia życzyłby sobie mieć prawo do nazwy. Nie znana jest reakcja lekarza na odpowiedź prof. Stromeyera, który oświadczył, że rzeczywiście jest to nowy pierwiastek, który naukowiec z Getyngi już zdążył nazwać kadmium. Musiała być jednak dość gwałtowna, gdyż w latach 1818-1821 rozgorzała naukowa burza o palmę pierwszeństwa odkrycia nowego pierwiastka, która zaowocowała szeregiem polemicznych artykułów. Do dyskusji oprócz Stromayera, Roloffa i Hermanna włączyło się jeszcze kilku chemików i farmaceutów publikując swoje doniesienia ${ }^{14}, 15,16,17,18$. Nowemu metalowi nadawano nazwy takie jak: melinium, junonium, vestaeium, vodanium czy sirium. Ostatecznie jednak środowisko naukowe przyznało prawo do nazwy, a tym samym miano odkrywcy Friedrichowi Stromayerowi. Dziś, z perspektywy czasu, wydaje się jednak, że oprócz profesora z Getyngi równorzędne miejsce w historii odkrycia kadmu powinno przypaść również Johannowi Roloffowi oraz Carlowi Hermanowi, co też podkreślane jest coraz częściej w oficjalnych informacjach z dziedziny chemii ${ }^{19}$. Bezspornym za to i wartym podkreślenia faktem jest, iż kadm był historycznie pierwszym metalem wyizolowanym ze składnika ubocznego rudy innego pierwiast-

11 Tamże, s. 303 .

12 J.C.H. Roloff: Fortgesetzte Untersuchungen über die Reinheit der Zinkblumen, und wahrscheinliche Entdeckung eines neuen Metalls in denselben“, „Journal der Praktischen Heilkunde" 4: 1818 s. 126-129.

${ }^{13}$ H. Stabe roh: Ueber ein wahrscheinlich neues Metall, im schlesischen Zink, „Museum des Neuesten und Wissenswürdigsten aus dem Gebiete der Naturwissenschaft, der Künste, der Fabriken, der Manufakturen, der technischen Gewerbe, der Landwirthschaft, der Produkten-, Waaren- und Handelskunde, und der bürgerlichen Haushaltung : für gebildete Leser und Leserinnen aus allen Ständen” 14: 1818 nr 2 s. 125-132.

${ }^{14}$ K.S.L. H er ma n n: Noch ein Schreiben über das neue Metall, „Annalen der Physik” 29: 1818 s.113-116.

${ }^{15}$ F. Stromeyer: Ueber das Kadmium, „Annalen der Physik” 30: 1818 s. 193-210.

${ }^{16} \mathrm{~J}$. Ro l off: Zur Geschichte des Kadmium, „Annalen der Physik” 31: 1819 s. 205-210.

${ }^{17}$ K.S.L. Herman n: Ueber das Zinkoxyd und den Kadmium Gehalt desselben, „Annalen der Physik" 31: 1820 s. 276-289.

${ }^{18}$ L. Von Vest: Darstelung und Eigenschaften des Vestäium oder Vestium, eines neuentdeckten Metalls, „Annalen der Physik” 29: 1818 s. 387-411.

${ }^{19}$ N. Tarakina, B. Verberck: A portrait of cadmium, „Nature Chemistry” 9: 2017 s. 96. 
ka. Stało się to możliwe dzięki, stosunkowo zaawansowanemu już w tym okresie rozwojowi chemii analitycznej.

\section{Nazwa}

Nazwa kadm pochodzi od greckiego słowa kadmeia, będącego dawnym określeniem rudy cynku: kalaminu, w której to Stromayer wykrył nowy pierwiastek. Kadmeia natomiast swój źródłosłów zawdzięcza mitycznemu herosowi Kadmosowi. Według mitologii greckiej półbóg ten był synem Agenora - króla Tyru i Telefassy - królowej fenickiej. W poszukiwaniu swojej siostry Europy, uprowadzonej przez Zeusa, trafił do wyroczni delfickiej, która kazała mu iść za napotkaną w polu jałówką i założyć nowy gród tam, gdzie ona się zatrzyma. Wykonując to zadanie, założył w Beocji Kadmeę, czyli późniejsze Teby. A właśnie w Grecji centralnej i południowo-wschodniej występują liczne złoża rudy miedzi i cynku, eksploatowane już od starożytności ${ }^{20}$.

\section{Źródła pozyskiwania kadmu}

Wprawdzie kadm należy do pierwiastków występujących na Ziemi stosunkowo często - zajmuje pod względem rozpowszechniania 48 miejsce, a jego udział w chemicznym składzie skorupy ziemskiej ocenia się na 0,00002-0,00005\%, jednak występuje on w znacznym rozproszeniu (co utrudniało jego odkrycie). Minerały kadmu: grenokit $\mathrm{CdS}$ oraz otawit $\mathrm{CdCO}_{3}$ występują rzadko. Produkcja tego pierwiastka opiera się niemal wyłącznie na rudach cynku, które zawierają domieszki związków kadmu przeważnie w ilości ok. 0,1\%. Wartym odnotowania jest fakt, że aż do 1918 r. głównym miejscem pozyskiwania kadmu i jego produkcji był Śląsk. Tamtejsze galmanowe złoża rud cynku i ołowiu były bowiem szczególnie bogate w ten metal ${ }^{21}{ }^{22}$. Jednak po ich wyczerpaniu na czoło producentów kadmu wysunęły się w owym czasie Stany Zjednoczone i Australia ${ }^{23},{ }^{24}$. Obecnie głównymi producentami kadmu są Chiny, Korea Południowa i Japonia, przy czym prawie jedna czwarta produkcji opiera się na recyklingu zużytych baterii $\mathrm{Ni}-\mathrm{Cd}^{25}$.

${ }^{20}$ G. Rapp: Archaeomineralogy, Berlin-Heidelberg 2009, s 178-180.

${ }^{21}$ W. Łos ki ewicz: Kadm, „Przegląd Górniczo-Hutniczy” 22 (395): 1927 s. 678-680.

${ }^{22}$ B. N e u m a n n: Die Metalle: Geschichte, Vorkommen und Gewinnung, nebst ausführlicher Produktions- und Preis-Statistik, Halle 1904, s. 321-325.

${ }^{23}$ W. Łoskiewicz: Kadm... s. 680.

${ }^{24}$ A. Frużyński: Industrializacja Górnego Śląska do 1922 roku [w:] Encyklopedia Województwa Śląskiego, 2016, T.3, zasób internetowy: http://ibrbs.pl/mediawiki/index.php/ Industrializacja_G\%C3\%B3rnego_\%C5\%9Al\%C4\%85ska_do_1922_roku, dostęp 22.09.2017.

${ }^{25} \mathrm{http}: / /$ www.cadmium.org/introduction, dostęp 22.09.2017. 


\section{Zastosowanie kadmu od XIX po XXI wiek}

Nowo odkryty pierwiastek już od połowy XIX wieku zyskiwał coraz szersze zastosowanie. Dodatek tego metalu do stopów srebra i złota zwiększał ich kowalność. Kadm w amalgamacie próbowano również wykorzystywać w stomatologii ${ }^{26}$. Najszybciej pierwiastek ten jednak zrobił karierę w malarstwie. Bogatą gamę intensywnych kolorów uzyskiwanych w pigmentach opartych na solach kadmu zaczęli wykorzystywać malarze, w tym tak sławni jak Vincent Van Gogh, Claude Monet czy Henri Mattise. W literaturze tematu pojawiają się nawet sugestie, iż rozwój takich kierunków w sztuce jak ekspresjonizm, czy fowizm był możliwy między innymi dzięki odkryciu pigmentów na bazie soli kadmu ${ }^{27},{ }^{28}$.

Pigmenty kadmowe posiadają również dodatkowe zalety, docenione i wykorzystywane od szeregu lat w przemyśle. Są nimi doskonała zdolność krycia oraz odporność na wysokie temperatury i działanie promieni słonecznych. Dlatego też pigmenty te są powszechnym składnikiem farb stosowanych w celach przemysłowych, w tym do pokrywania elementów gorących.

Intensywne kolory związków kadmu spowodowane są faktem, iż omawiane sole są półprzewodnikami. Przerwa energetyczna pomiędzy pasmem walencyjnym i pasmem przewodnictwa przypada na zakres światła widzialnego. Przykładowo, w przypadku siarczku kadmu wartość przerwy energetycznej wynosi 2,42eV, co odpowiada energii fali światła o długości $512 \mathrm{~nm}$. CdS absorbuje więc światło niebieskozielone, co odbieramy jako barwę żółtą. Ponadto, w przypadku omawianej soli, współczynniki absorpcji w tym zakresie fal są bardzo wysokie, dzięki czemu postrzegana barwa jest tak intensywna. Nowoczesne pigmenty kadmowe mogą być stosowane w formie nanocząstek - kropek kwantowych o rozmiarach mniejszych niż $10 \mathrm{~nm}$. Od wymiarów tych nanokryształów silnie zależy wielkość wspomnianej wcześniej przerwy energetycznej (jest to tzw. efekt kwantowania rozmiaru). Dzięki temu, zmieniając rozmiar używanych nanocząstek zmienia się wielkość przerwy energetycznej (im mniejsza kropka kwantowa, tym większa przerwa), co wpływa na barwę pigmentu.

Wspomniane wyżej kropki kwantowe oparte m.in. na związkach kadmu znalazły również zastosowanie w dziedzinach dalekich od malarstwa, a mianowicie w biologii i medycynie. Modyfikowane właściwymi ligandami mogą być użyte w znakowaniu

${ }^{26}$ Cadmium Encyclopedia Britannica 11th edition, vol 4 s. 930-931, New York 1911.

${ }^{27}$ K. Janssens, G. Van der Snickt, F. Vanmeert, S. Legrand, G. Nuyts, M. Alfeld, L. Monico, W. Anaf, W. De Nolf, M. Vermeulen, J. Verbeeck, K. De Wael: Non-Invasive and Non-Destructive Examination of Artistic Pigments, Paints, and Paintings by Means of X-Ray Methods [w:] Analytical Chemistry for Cultural Heritage, [w:] Analytical Chemistry for Cultural Heritage, red. R. M a z z e o, Norwich 2017, s. 77-128

${ }^{28}$ S. Everts: Van Gogh's Fading Colors Inspire Scientific Inquiry. Lessons learned from the chemical breakdown of pigments in the Post-Impressionist's masterpieces, „Chemical \& Engineering News" 94: 2016 nr 5 s. 32-33. 
powierzchni komórek i struktur wewnątrzkomórkowych zarówno w preparatach utrwalonych, jak również w żywych komórkach. Właściwości kropek kwantowych jako nanoznaczników umożliwiają długotrwałe monitorowanie znakowanego elementu, na przykład receptora powierzchni błony komórkowej ${ }^{29}$.

Nagły wzrost produkcji kadmu na początku XX wieku i objęcie prymatu przez USA nie było jednak związane z barwiarstwem, a ze skokowym wzrostem popytu na ten metal w przemyśle elektromaszynowym. Od lat 20. ubiegłego wieku pierwiastek ten zaczął być powszechnie wykorzystywany w galwanizerniach do pokrywania powierzchni stalowych. Okazało się bowiem, iż kadm ma porównywalne a nawet w niektórych przypadkach lepsze właściwości ochronne w stosunku do żelaza niż droższy w produkcji cynk. Różnica ta jest szczególnie widoczna w atmosferach stosunkowo mało zanieczyszczonych i o dużej wilgotności, czyli np. w strefie tropikalnej. W odróżnieniu od cynku kadm nie wykazuje właściwości amfoterycznych, dzięki czemu jest również odporny na działanie alkaliów.

Analizując wykorzystanie kadmu przez człowieka, należy zauważyć, iż już od lat 80. XX wieku większość uzyskiwanego metalu zużywana jest w szeroko pojmowanej energetyce. Obecnie gałęzią przemysłu wykorzystującą ponad 80\% rafinowanego kadmu jest produkcja akumulatorów niklowo-kadmowych. Akumulatory te wynalezione zostały już w 1899 r. przez szwedzkiego chemika Waldemara Jungera i od tamtej pory są powszechnie wykorzystywane zarówno w domowych urządzeniach przenośnych jak i w przemyśle. 0 ile jednak w tych pierwszych od kilku lat są skutecznie wypierane przez bezpieczniejsze dla środowiska akumulatory litowo-jonowe i niklowo-wodorkowe, to w przemyśle nadal są póki co niezastąpione. Decyduje o tym, oprócz ceny, ich trwałość, szybkość ładowania i odporność na korozję $e^{30}$.

W typowym akumulatorze Ni-Cd katodę stanowi zasadowy tlenek niklu(III) o barwie czarnej, natomiast anodą jest metaliczny kadm. Rolę elektrolitu spełnia zazwyczaj wodorotlenek potasu. Reakcje zachodzące podczas rozładowania ogniwa i produkcji prądu można przedstawić następująco:

anoda: $\quad \mathrm{Cd}+2 \mathrm{OH}^{-} \rightarrow \mathrm{Cd}(\mathrm{OH})_{2}+2 \mathrm{e}^{-}$

katoda: $\quad 2 \mathrm{NiO}(\mathrm{OH})+2 \mathrm{H}_{2} \mathrm{O}+2 \mathrm{e}^{-} \rightarrow 2 \mathrm{Ni}(\mathrm{OH})_{2}+2 \mathrm{OH}^{-}$

Sumarycznie mamy więc reakcję:

$2 \mathrm{NiO}(\mathrm{OH})+\mathrm{Cd}+2 \mathrm{H}_{2} \mathrm{O} \rightarrow 2 \mathrm{Ni}(\mathrm{OH})_{2}+\mathrm{Cd}(\mathrm{OH})_{2}$

$\mathrm{Na}$ anodzie kadm utlenia się i powstaje biały wodorotlenek kadmu, na katodzie natomiast na skutek redukcji niklu(III) powstaje jasnoniebieski wodorotlenek

${ }^{29}$ V.I. Kochubeia, I.D. Kosobudskii, Y.G. Konyukhovaa, I.V. Zabenkova: Luminescence of Polymer Composite Materials with Cadmium Sulfide Nanoparticles „High Energy Chemistry" 44: $2010 \mathrm{nr} 2$ s. 153-157.

${ }^{30}$ A.C. Tolcin: 2015 Minerals Yearbook - cadmium U.S. Department of the Interior, U.S. Geological Survey 2016, zasób internetowy: https://minerals.usgs.gov/minerals/pubs/commodity/cadmium/myb1-2015-cadmi.pdf dostęp 22.09.2017. 
niklu(II). Napięcie takiego ogniwa to ok. 1,25-1,35 V. W trakcie ładowania akumulatora kierunek opisanych reakcji chemicznych jest odwrotny.

Akumulatory oparte na kadmie, to najpopularniejsze, choć nie jedyne wykorzystanie tego pierwiastka w energetyce. Inne to pręty kontrolne, będące jednym z elementów rdzenia reaktora jądrowego. Dzięki zdolnościom pochłaniania neutronów, kadm umożliwia kontrolę tempa łańcuchowej reakcji rozszczepienia. Pręty ze stopu srebra kadmu oraz indu są stosowane w najbardziej rozpowszechnionym typie reaktora jądrowego - reaktorze wodnym - ciśnieniowym (PWR). Kadm znalazł również zastosowanie energetyce odnawialnej, a dokładnie w ogniwach fotowoltaicznych. Elementem półprzewodnikowym w tak zwanym ogniwie drugiej generacji jest bowiem tellurek kadmu (CdTe). W technologii tej wydajność ogniwa wynosi obecnie już ponad 20\%, co w przypadku pozyskiwania energii elektrycznej ze Słońca jest bardzo satysfakcjonującym wynikiem. Dodatkowo stosunkowo niskie zużycie materiału półprzewodnikowego powoduje, że ogniwa te są trwałe, a co za tym idzie, nieco tańsze w użytkowaniu niż tradycyjne ogniwa krzemowe ${ }^{31}$.

Obecnie liderami w wykorzystaniu kadmu są trzy kraje. Pierwsze dwa to Chiny i Japonia, gdzie produkuje się większość akumulatorów Ni-Cd. Są one odpowiedzialne za niemal połowę światowego popytu na kadm. Trzecim krajem, na który przypada około jednej trzeciej światowej konsumpcji kadmu jest Belgia, gdzie działa koncern Flaurea Chemicals produkujący sole kadmu do wszelakich omówionych wyżej celów, począwszy od pigmentów, a na przemyśle fotowoltaicznym kończąc ${ }^{32}$.

Warto również wspomnieć o ciekawym, acz stosunkowo mało znanym fakcie wykorzystania kadmu w metrologii. W 1907 r. Międzynarodowa Unia Astronomiczna zdefiniowała jednostkę miary angstrem poprzez długość fali czerwonej linii widmowej właśnie kadmu w powietrzu, której przypisano wartość dokładnie 6438,4696 A. Definicja ta została podtrzymana przez Międzynarodowe Biuro Miar i Wag w 1927 r. i była w tej formie wykorzystywana aż do 1960 r., kiedy to zdefiniowano metr $\mathrm{w}$ jednostkach długości fali promieniowania kryptonu, a angstrem został zdefiniowany jako $10^{-10} \mathrm{~m}$. Inicjatorem ścisłego zdefiniowania angstrema w opisany sposób był amerykański fizyk, urodzony w Strzelnie na Kujawach, Albert Michealson, znany w środowisku naukowym m.in. jako twórca interferometru. Michaelson zmierzył wzorzec metra przechowywanego w Sevres pod Paryżem, pokazując, że jego długość jest równa 1553163,5 długości fal właśnie czerwonego światła emitowanego przez kadm. Za to oraz inne osiągnięcia z metrologii i spektroskopii otrzymał on w 1907 r. nagrodę Nobla ${ }^{33}$.

\footnotetext{
31 Tamże.

32 Tamże.

${ }^{33}$ C. D ot s o n : Fundamentals of Dimensional Metrology, New York 2015 s. 446-447.
} 


\section{Kadm a zdrowie człowieka}

Omawiając wpływ kadmu na ludzkość nie można jednak pominąć jego drugiej „ciemnej strony”. Zarówno krótko- jak i długotrwałe oddziaływanie kadmu na organizm ludzki doprowadza bowiem do szeregu uszkodzeń w narządach, w których łatwo się on akumuluje, głównie w płucach, wątrobie, kościach i nerkach.

Najczęściej przytaczanym przykładem masowej kadmicy jest przypadek kilkudziesięcioletniego zatruwania mieszkańców prefektury Toyama w środkowej części wyspy Honsiu w Japonii. Znajdujące się w tym terenie kopalnie metali nieżelaznych Kamioka od 1910 roku przez około 50 lat wprowadzały związki kadmu do pobliskich rzek, których wody wykorzystywane były w celach gospodarczych przez okolicznych mieszkańców. Wieloletnia intoksykacja kadmem spowodowała szereg dysfunkcji, z których najbardziej charakterystyczną była deformacja sylwetki i związane z nią łamliwość oraz odwapnienie kości. Od japońskiego słowa określającego ból: itai zespół chorobowy przewlekłego zatrucia kadmem został nazwany chorobą itai-itai $^{34,35}$.

\section{Molekularne skutki toksycznego działania kadmu}

Mechanizm toksyczności kadmu na organizmy na poziomie komórkowym nie jest jeszcze do końca poznany. Najbardziej narażone na oddziaływanie kadmu są mitochondria. Jony $\mathrm{Cd}^{2+}$, wykorzystując swoje podobieństwo w budowie do jonów $\mathrm{Ca}^{2+}$, wnikają przez kanały wapniowe do błon mitochondrialnych i modyfikują ich przepuszczalność. Prowadzi to do zaburzenia podstawowej funkcji mitochondriów - produkcji energii dla komórki. Dodatkowo zmiany błony mitochondrialnej i wynikające z niej zaburzenia szeregu reakcji chemicznych powodują uwalnianie wolnych rodników nieodwracalne uszkadzających te organella. Dłuższe narażenie na zatrucie kadmem przyczynia się również do spadku aktywności niektórych enzymów. Jest to spowodowane wymianą jonów $\mathrm{Zn}^{2+}, \mathrm{Cu}^{2+}, \mathrm{Mn}^{2+} \mathrm{czy} \mathrm{Fe}^{2+}$, znajdujących się w centrach aktywnych tych enzymów, przez jony $\mathrm{Cd}^{2+}$, co powoduje ich unieczynnienie. Najczęściej są to enzymy naprawcze DNA oraz enzymy antyoksydacyjne chroniące komórki przed negatywnymi skutkami działania reaktywnych form tlenu, co zdecydowanie zwiększa prawdopodobieństwo zmian nowotworowych. Kadm we krwi w podobnysposóbjakw mitochondriachsiejezniszczeniew erytrocytach. Naruszabowiem cytoszkielet, powodując jego dysfunkcję, a finalnie prowadzi do apoptozy czerwonych krwinek. Najbardziej z kolei widoczne w chorobie itai-itai zmiany w układzie

${ }^{34}$ I. Krzywy, E. Krzywy, J. Peregud-Pogorzelski, K. Łuksza, A. Brodkiewicz: Cadmium - Is There Something To Fear?, „Annales Academiae Medicae Statinensis” 75: 2011 nr 3 s. 49-63.

${ }^{35}$ M. Ja ku b o w s ki: Kadm i jego zwiq̨zki nieorganiczne - w przeliczeniu na Cd, „Podstawy i Metody Oceny Środowiska Pracy" 2 (72): 2012 s. 124. 
kostnym wynikają najprawdopodobniej z faktu nienaturalnego pobudzenia przez ten pierwiastek osteoklastów, jednoczesnego hamowania metabolizmu witaminy D oraz utraty wraz z moczem wapnia na skutek uszkodzenia nerek ${ }^{36,37}$.

Przedstawione powyżej skutki narażenia na toksyczne oddziaływanie kadmu, połączone z jego zdolnością akumulacji w organizmie powodują, iż pierwiastek ten pomimo niewątpliwych zasług, jakie oddał i nadal oddaje ludzkości, znajduje się na czarnej liście toksyn, zbędnych do funkcjonowania znaczącej większości organizmów żywych.

\section{PIŚMIENNICTWO}

Cadmium Encyclopedia Britannica 11th edition, vol. 4 s. 930-931, New York 1911.

Czeczot H. Majewska M.: Kadm - zagrożenie i skutki zdrowotne „Farmacja Polska” 2010, 66 (04), s. 243-250.

D ots o n C.: Fundamentals of Dimensional Metrology, New York 2015 s. 446-447.

Everts S.: Van Gogh's Fading Colors Inspire Scientific Inquiry. Lessons learned from the chemical breakdown of pigments in the Post-Impressionist's masterpieces, „Chemical \& Engineering News" 2016, vol. 94, issue 5 s. 32-33.

Fontani M., Costa M., Orna M. V.: The Lost Elements: The Periodic Table's Shadow Side, New York 2014, s. 59 - 61.

Frużyński A.: Industrializacja Górnego Śląska do 1922 roku [w:] Encyklopedia Województwa Śląskiego, 2016, T.3, zasób internetowy http://ibrbs.pl/mediawiki/index.php/Industrializacja_G\%C3\%B3rnego_\%C5\%9Al\%C4\%85ska_do_1922_roku, dostęp 22.09.2017.

H e rm a n K. S. L.: Noch ein Schreiben über das neue Metall, „Annalen der Physik“ 1818, 29, s. 113-116.

Her m an n K. S. L.: Ueber das Zinkoxyd und den Kadmium Gehalt desselben, „Annalen der Physik“ 1820, 31, s. 276-289.

Hirsch A., Werni ch A., Gurlt E. J.: Biographisches Lexikon der hervorragenden Aerzte aller Zeiten und Völker, Wien 1886, vol. 5, s. 566.

Jakubowski M.: Kadm i jego związki nieorganiczne - w przeliczeniu na Cd, „Podstawy i Metody Oceny Środowiska Pracy" 2012 vol 2 (72), s. 111-146.

Janssens K., Van der Snickt G., Vanmeert F., Legrand S., Nuyts G., Alfeld M., Monico L., Anaf W., De Nolf W., Vermeulen M., Verbeeck J., De Wael K.: Non-Invasive and Non-Destructive Examination of Artistic Pigments, Paints, and Paintings by Means of X-Ray Methods in Analytical Chemistry for Cultural Heritage, [w:] Analytical Chemistry for Cultural Heritage, red. Mazzeo R., Norwich 2017, s.77-128.

${ }^{36} \mathrm{H}$. Czeczot, M. Majewska: Kadm - zagrożenie i skutki zdrowotne „Farmacja Polska” 2010, 66 (04), s. 247-249.

${ }^{37}$ V. Mly ne k, A. S ko c zy ń s ka: Prozapalne działanie kadmu, „Postępy Higieny i Medycyny Doświadczalnej" 59: 2005 s. 1-8. 
Kochubeia V. I., Kosobudskiib I. D., Konyukhovaa Y. G., Zabenkova I.V.: Luminescence of Polymer Composite Materials with Cadmium Sulfide Nanoparticles „High Energy Chemistry", 2010, vol. 44, no. 2, s. 153-157.

Krzywy I., Krzywy E., Peregud-Pogorzelski J. Łuksza K., Brodkiewicz A.: Cadmium - Is There Something To Fear?, „Annales Academiae Medicae Statinensis” 2011, vol 57, (3), s. 49-63.

Lo ckem an n G., O e s p er R. E.: Friedrich Stromeyer and the history of chemical laboratory instruction, „Journal of Chemical Education” 1953, 30 (4), s. 202-204.

Łos ki e wi cz W.: Kadm, „Przegląd Górniczo-Hutniczy” 1927, 22 (395), s. 678-680.

Mlynek V., Skoczyń ska A.: Prozapalne działanie kadmu”, „Postępy Higieny i Medycyny Doświadczalnej" 2005, vol 59, s. 1-8.

Neumann B.: Die Metalle: Geschichte, Vorkommen und Gewinnung, nebst ausführlicher Produktions- und Preis-Statistik, Halle 1904, s. 321-325.

Rapp G., Archaeomineralogy, Berlin-Heidelberg 2009, s 178-180.

Rol off J. C. H.: Fortgesetzte Untersuchungen über die Reinheit der Zinkblumen, und wahrscheinliche Entdeckung eines neuen Metalls in denselben“, „Journal der Praktischen Heilkunde“ 1818, IV s.126-129.

Rol off J. C. H: Zur Geschichte des Kadmium, „Annalen der Physik“1819, 31, s. 205-210.

Róż ań s ki H.: Tlenek cynku - Zincum oxydatum w medycynie XVIII i XIX wieku, [w:] Medycyna dawna i współczesna. Zasób internetowy: http://rozanski.li/1495/tlenek-cynku-zincum-oxydatum-w-medycynie-xviii-i-xix-wieku/ dostęp 22.09.2017.

Stab er o h H.: Ueber ein wahrscheinlich neues Metall, im schlesischen Zink, „Museum des Neuesten und Wissenswürdigsten aus dem Gebiete der Naturwissenschaft, der Künste, der Fabriken, der Manufakturen, der technischen Gewerbe, der Landwirthschaft, der Produkten-, Waaren- und Handelskunde, und der bürgerlichen Haushaltung: für gebildete Leser und Leserinnen aus allen Ständen" 1818, 14., H. 2 s. 125-132.

Stromeyer F.: Ein neu entdecktes Metall und Analyse eines neuen Minerals, „Journal für Chemie und Physik“ 1817, vol.21, s. 297-306.

Stro m e y er F.: Ueber das Kadmium, „Annalen der Physik“ 1818, 30, s. 193-210.

Tarakina N., Verberck B.: A portrait of cadmium, „Nature Chemistry”, 2017, 9, s. 96.

Tolcin A. C.: 2015 Minerals Yearbook - cadmium U.S. Department of the Interior, U.S. Geological Survey 2016, zasób internetowy: https://minerals.usgs.gov/minerals/pubs/commodity/cadmium/myb1-2015-cadmi.pdf dostęp 22.09.2017.

Tu rn er E.: Elements of chemistry including the recent discoveries and doctrines of the science, Philadelphia 1832 s. 337.

Von Vest L.: Darstelung und Eigenschaften des Vestäium oder Vestium, eines neuentdeckten Metalls, „Annalen der Physik“ 1818 29, s. 387-411.

www.cadmium.org/introduction, dostęp 22.09.2017. 